\title{
Preoperative serum carcinoembryonic antigen levels are associated with histologic subtype, EGFR mutations, and ALK fusion in patients with completely resected lung adenocarcinoma
}

\author{
This article was published in the following Dove Press journal: \\ OncoTargets and Therapy \\ 7 July 2017 \\ Number of times this article has been viewed
}

\section{Zeng Wang' \\ Shifeng Yang ${ }^{2}$ \\ Hongyang $\mathrm{Lu}^{3,4}$ \\ 'Department of Pharmacy, \\ ${ }^{2}$ Department of Pathology, ${ }^{3}$ Zhejiang \\ Key Laboratory of Diagnosis and \\ Treatment Technology on Thoracic \\ Oncology (Lung and Esophagus), \\ Zhejiang Cancer Hospital, Hangzhou, \\ ${ }^{4}$ Department of Oncology, Wenzhou \\ Medical University, Wenzhou, People's \\ Republic of China}

Correspondence: Hongyang Lu Zhejiang Key Laboratory of Diagnosis and Treatment Technology on Thoracic Oncology (Lung and Esophagus), Zhejiang Cancer Hospital, I East Banshan Road, Gongshu District, Hangzhou 310022, People's Republic of China

Tel +8657188122094

Fax +86 57I 88I2 2508

Email luhy@zjcc.org.cn
Background: Serum carcinoembryonic antigen (CEA) is often elevated in lung adenocarcinoma, but not in all patients. Meanwhile, epidermal growth factor receptor (EGFR) mutations and anaplastic lymphoma kinase (ALK) fusion protein are the main driving forces in lung adenocarcinoma. However, whether CEA levels are associated with histologic subtype, EGFR mutations, and ALK fusion remain largely unclear.

Methods: Preoperative serum CEA levels, postoperative histologic subtypes, and statuses of EGFR mutations and ALK fusion protein were retrospectively assessed in 442 patients with completely resected lung adenocarcinoma treated from January 2014 to December 2015 at Zhejiang Cancer Hospital, People's Republic of China.

Results: EGFR mutations were found in 69.9\% (309/442) of lung adenocarcinoma patients, and ALK fusion protein in 4.5\% (20/442). EGFR mutations occurred more frequently in the lepidic subtype $(P=0.001)$. High preoperative serum CEA levels $(C E A>20 \mathrm{ng} / \mathrm{mL})$ were independently associated with EGFR mutations $(P<0.001)$. Moreover, in patients with CEA levels of $21-49 \mathrm{ng} / \mathrm{mL}$, the EGFR mutation rate was $88.2 \%$, which was higher compared to those obtained in the other subgroups. In addition, all specimens were invasive adenocarcinoma, with lepidic (18.6\%), papillary (15.4\%), acinar (52.7\%), solid (9.7\%), micropapillary $(3.2 \%)$, and mucinous predominant $(0.4 \%)$ subtypes; CEA levels in patients with the solid subtype were higher than those of other histologic subtypes $(P=0.001)$.

Conclusion: Preoperative serum CEA levels can serve as a reference marker to identify the histologic subtype, and EGFR mutation or ALK fusion protein status, in lung adenocarcinoma patients. Moreover, histological subtypes could also predict EGFR mutations.

Keywords: lung adenocarcinoma, carcinoembryonic antigen, EGFR, ALK, histologic subtype

\section{Introduction}

Lung adenocarcinoma subtypes, including lepidic, papillary, acinar, solid, micropapillary, and mucinous predominant, have been defined by the new International Association for the Study of Lung Cancer/American Thoracic Society/European Respiratory Society (IASLC/ATS/ERS) international histological classification. Epidermal growth factor receptor (EGFR) mutations easily occur in lung adenocarcinoma patients, especially in females and non-smokers. The rates of EGFR mutations in lung adenocarcinoma in People's Republic of China are higher than those of Caucasian populations. ${ }^{1-3}$ EGFRtyrosine kinase inhibitors are considered the first-line therapeutics for lung adenocarcinoma harboring EGFR mutations. ${ }^{4,5}$ Anaplastic lymphoma kinase (ALK) fusion protein 
is present in about $5 \%$ of lung adenocarcinoma cases. ${ }^{6,7}$ ALK inhibitors are superior to chemotherapy in lung adenocarcinoma patients with ALK rearrangement, improving symptoms and quality of life. ${ }^{8-10} \mathrm{~A}$ higher intracranial disease control rate in patients with brain metastasis was also demonstrated for ALK inhibitors compared with chemotherapy. ${ }^{11,12}$ Both EGFR and $A L K$ are the main driving genes in lung adenocarcinoma.

Serum carcinoembryonic antigen (CEA) levels are usually elevated in lung adenocarcinoma patients, constituting an effective and noninvasive method for the diagnosis of this malignancy. ${ }^{13,14}$ CEA levels are independently associated with $E G F R$ gene mutations, and the frequency of $A L K$ fusion gene among patients with a serum CEA concentration below $5 \mathrm{ng} / \mathrm{mL}$ seems to be higher than that of patients with a concentration above $5 \mathrm{ng} / \mathrm{mL}(P=0.021) .{ }^{15} \mathrm{CEA}$ levels in patients with EGFR mutations and ALK fusion protein might be different from those of cases with no EGFR mutation or ALK fusion protein. As the lung cancer research field is rapidly evolving, molecular pathology attracts increasing attention. Meanwhile, information regarding the clinical characteristics and molecular pathology of lung adenocarcinoma subtypes as defined by the new IASLC/ATS/ERS classification remains limited. There may be also differences in CEA levels among the histologic subtypes of lung adenocarcinoma.

This study aimed to further assess the associations of CEA levels with histologic subtype, and the status of EGFR mutations and ALK fusion protein. A total of 442 patients were assessed, and clinicopathological parameters, serum CEA levels, and the status of EGFR mutations and ALK fusion protein were analyzed.

\section{Methods}

\section{Patients and eligibility criteria}

A total of 442 cases with completely resected lung adenocarcinoma (184 males and 258 females), treated from January 2014 to December 2015 in Zhejiang Cancer Hospital, People's Republic of China, were retrospectively assessed.

Inclusion criteria were stage IA-IIIA completely resected lung adenocarcinoma and 18 years of age or older. Patients were excluded from the study for any of the following reasons: 1) history of other malignancy (unless more than 5 years of disease-free state), except completely resected non-melanoma skin cancer; 2) preoperative anticancer therapy, eg, radiotherapy and chemotherapy; 3 ) preoperative CEA not detected; and 4) no EGFR and ALK detection after operation.

\section{Patient characteristics}

Median age was 61 years (range, 30-81 years). Of the 442 patients, 331, 42, 34, and 54 were non-smokers, light smokers, moderate smokers, and heavy smokers, respectively. Lung adenocarcinoma patients were divided (as proposed by the seventh edition of the TNM classification for lung cancer) as follows: 140 cases with stage IA, 140 with stage IB, 41 with stage IIA, 15 with stage IIB, and 96 with stage IIIA. In detail, 119 cases with T1a, 70 with T1b, 210 with T2a, 21 with T2b, 16 cases with T3, and 15 with T4 disease stage were included. Meanwhile, there were 311 cases with N0, 41 with N1, and 90 with N2. In the patients, preoperative CEA levels detected by chemiluminescent microparticle immunoassay (ARCHITECT i4000 chemiluminescence analyzer; Abbott, Chicago, IL, USA), EGFR mutation status assessed by amplification refractory mutation system (ARMS), and ALK fusion protein detected by Ventana (D5F3) immunohistochemistry assay (Ventana Medical Systems; Roche, Inc., Tucson, AZ, USA) were retrospectively evaluated. The current retrospective study was approved by the Medical Ethics Review Committee of Zhejiang Cancer Hospital, and exemption from written informed consent was also approved by the Medical Ethics Committee of Zhejiang Cancer Hospital. Most of the patients in this retrospective study signed the written informed consent before surgery to preserve their specimens in the Biological Sample Bank of Zhejiang Cancer Hospital to be used in research.

\section{CEA detection}

Blood samples were collected before surgery, and CEA amounts were analyzed in the clinical laboratory of our hospital.

\section{EGFR mutation and ALK fusion detection}

Pathological tissues were sent to the Department of Pathology after surgery, EGFR mutation was detected by using ARMS and ALK fusion was detected by using Ventana immunohistochemistry according to routine method. ${ }^{16,17}$

\section{Statistical analyses}

The SPSS software version 15.0 (Chicago, IL, USA) was used for all analyses. Data were assessed by the chi-square test, with $P<0.05$ considered statistically significant. A regression hazards model was used for univariate and multivariate analyses to assess the prognostic value of preoperative serum CEA levels.

\section{Results}

\section{Serum carcinoembryonic antigen levels and lung adenocarcinoma histologic subtypes}

Median serum CEA levels were $2.47 \mathrm{ng} / \mathrm{mL}$, ranging from $<0.5$ to $623.54 \mathrm{ng} / \mathrm{mL}$. Meanwhile, 310 patients had 
Table I Correlation between serum CEA level and lung adenocarcinoma histologic subtype

\begin{tabular}{|c|c|c|c|c|c|}
\hline Histologic subtype & $n=442$ & $\begin{array}{l}\text { CEA }>5 \mathrm{ng} / \mathrm{mL} \\
(\mathrm{n}=132)\end{array}$ & $\begin{array}{l}\text { CEA } \leq 5 \mathrm{ng} / \mathrm{mL} \\
(\mathrm{n}=3 \mid 0)\end{array}$ & $P$-value & Chi-square \\
\hline Acinar & 233 & 78 (59\%) & $155(50 \%)$ & 0.000 & 24.223 \\
\hline Lepidic & 82 & $10(7.6 \%)$ & $72(23.2 \%)$ & & \\
\hline Papillary & 68 & $18(13.6 \%)$ & $50(16.1 \%)$ & & \\
\hline Micropapillary & 14 & $3(2.3 \%)$ & II (3.5\%) & & \\
\hline Solid & 43 & $22(16.7 \%)$ & $21(6.8 \%)$ & & \\
\hline Mucinous predominant & 2 & I (0.8\%) & I $(0.3 \%)$ & & \\
\hline
\end{tabular}

Abbreviation: CEA, carcinoembryonic antigen.

serum CEA concentrations below $5 \mathrm{ng} / \mathrm{mL}$, and 132 patients had levels above $5 \mathrm{ng} / \mathrm{mL}$.

All cases were invasive adenocarcinoma, including 82 lepidic (18.6\%), 68 papillary (15.4\%), 233 acinar $(52.7 \%)$, 43 solid (9.7\%), 14 micropapillary (3.2\%), and two mucinous predominant $(0.4 \%)$ subtypes.

Furthermore, the correlation between serum CEA levels and the histologic subtype was analyzed. There were significant differences in histologic subtype between the $\mathrm{CEA}>5 \mathrm{ng} / \mathrm{mL}$ and $\mathrm{CEA} \leq 5 \mathrm{ng} / \mathrm{mL}$ groups $(P=0.000)$ (Table 1). Precisely, CEA levels in patients with the solid subtype were higher than those of other histologic subtypes. Meanwhile, more cases with the lepidic subtype were found in the CEA $\leq 5 \mathrm{ng} / \mathrm{mL}$ group compared with the CEA $>5 \mathrm{ng} / \mathrm{mL}$ group (Table 1 ).

\section{EGFR mutations and ALK fusion protein in lung adenocarcinoma specimens}

EGFR mutations were found in 309 cases, with a mutation rate of $69.9 \%$ (309/442). Among the patients, 135 had EGFR exon 19 mutations, 153 showed EGFR exon 21 mutations, and 26 had rare EGFR mutations. Meanwhile, ALK fusion was observed in 20 cases (4.5\%).

The associations of clinical features with EGFR mutations in patients with lung adenocarcinoma were analyzed (Table 2). EGFR mutations occurred more frequently in

Table 2 Clinical features in patients with lung adenocarcinoma with or without EGFR mutations

\begin{tabular}{|c|c|c|c|c|c|}
\hline Variables & $n=442$ & $\begin{array}{l}\text { EGFR mutation } \\
(n=309)\end{array}$ & $\begin{array}{l}\text { No EGFR mutation } \\
(n=133)\end{array}$ & $P$-value & Chi-square \\
\hline Sex & & & & 0.121 & 2.402 \\
\hline Male & 184 & 136 & 48 & & \\
\hline Female & 258 & 173 & 85 & & \\
\hline Age (years) & & & & 0.330 & 0.951 \\
\hline$<65$ & 308 & 211 & 97 & & \\
\hline$\geq 65$ & 134 & 98 & 36 & & \\
\hline Smoking status & & & & 0.328 & 0.956 \\
\hline No smoking & 311 & 212 & 99 & & \\
\hline Light smoking $(\leq 20)$ & 42 & 31 & 11 & & \\
\hline Moderate smoking (2I-39) & 35 & 27 & 8 & & \\
\hline Heavy smoking ( $\geq 40)$ & 54 & 39 & 15 & & \\
\hline $\mathrm{T}$ & & & & 0.239 & $\mathrm{I} .388$ \\
\hline Tla & 119 & 93 & 26 & & \\
\hline TIb & 70 & 53 & 17 & & \\
\hline $\mathrm{T} 2 \mathrm{a}$ & 210 & 136 & 74 & & \\
\hline $\mathrm{T} 2 \mathrm{~b}$ & 21 & 12 & 9 & & \\
\hline T3 & 16 & 10 & 6 & & \\
\hline $\mathrm{T} 4$ & 5 & 4 & I & & \\
\hline$N$ & & & & 0.000 & 26.080 \\
\hline No & 310 & 230 & 80 & & \\
\hline $\mathrm{NI}$ & 41 & 25 & 16 & & \\
\hline N2 & 90 & 53 & 37 & & \\
\hline Stage & & & & 0.000 & 26.968 \\
\hline IA & 150 & 120 & 30 & & \\
\hline IB & 140 & 100 & 40 & & \\
\hline
\end{tabular}

(Continued) 
Table 2 (Continued)

\begin{tabular}{|c|c|c|c|c|c|}
\hline Variables & $n=442$ & $\begin{array}{l}\text { EGFR mutation } \\
(n=309)\end{array}$ & $\begin{array}{l}\text { No EGFR mutation } \\
(n=133)\end{array}$ & $P$-value & Chi-square \\
\hline$\| \mathrm{A}$ & 41 & 21 & 20 & & \\
\hline IIB & 15 & 10 & 5 & & \\
\hline IIIA & 96 & 68 & 38 & & \\
\hline Histologic subtype & & & & 0.000 & 36.223 \\
\hline Acinar & 233 & 170 & 53 & & \\
\hline Lepidic & 82 & 68 & 14 & & \\
\hline Papillary & 68 & 49 & 19 & & \\
\hline Micropapillary & 14 & 8 & 6 & & \\
\hline Solid & 43 & 15 & 28 & & \\
\hline Mucinous predominant & 2 & 0 & 2 & & \\
\hline ALK fusion & 20 & 2 & 18 & 0.000 & $35.74 I$ \\
\hline
\end{tabular}

Abbreviations: EGFR, epidermal growth factor receptor; ALK, anaplastic lymphoma kinase; T, tumor; N, lymph node.

patients with IA, N0, lepidic subtype, and without ALK fusion protein $(P<0.000)$.

\section{Serum CEA levels and EGFR mutations/ ALK fusion protein}

Higher preoperative serum CEA levels (CEA $>20 \mathrm{ng} / \mathrm{mL}$ ) were independently associated with EGFR mutations $(P<0.001)$. In patients with CEA levels of $21-49 \mathrm{ng} / \mathrm{mL}$, the EGFR mutation rate was $88.2 \%$, which was higher compared with those obtained in cases with CEA levels of $<5 \mathrm{ng} / \mathrm{mL}$, 6-19 ng/mL, and $\geq 50 \mathrm{ng} / \mathrm{mL}$.

The EGFR 19 mutation incidence rate in patients with CEA levels of $21-49 \mathrm{ng} / \mathrm{mL}$ was the highest. However, the incidence rates of EGFR 21 mutations in all CEA level groups were similar (Table 3).

Although the incidence of ALK fusion in patients with CEA levels $\geq 50 \mathrm{ng} / \mathrm{mL}$ was the highest, the sample was too small.

\section{Serum CEA levels ( $>20 \mathrm{ng} / \mathrm{mL})$ and clinicopathologic characteristics}

As CEA levels (CEA $>20 \mathrm{ng} / \mathrm{mL}$ ) were independently associated with EGFR mutations, clinicopathologic characteristics between the CEA $>20 \mathrm{ng} / \mathrm{mL}$ and CEA $\leq 20 \mathrm{ng} / \mathrm{mL}$ groups were analyzed.

Univariate analysis showed that in addition to EGFR mutations, $\mathrm{T}$ and $\mathrm{N}$ stage and ALK fusion protein status were related to CEA levels (Table 4). Multivariate analysis is summarized in Table 5; EGFR mutations and T stage were independent risk factors for CEA.

\section{Discussion}

Serum CEA levels are a critical factor in predicting the efficacy of targeted therapy and chemotherapy, as well as postoperative recurrence and metastasis. However, the associations of CEA with histologic subtype, and EGFR mutations with ALK fusion gene in patients with completely resected lung adenocarcinoma remain unknown. The current study found that preoperative serum CEA levels can serve as a reference marker to identify the histologic subtype and EGFR mutation or ALK fusion protein status in lung adenocarcinoma patients.

High serum CEA is considered to be associated with more aggressive biologic features, suggesting that serum CEA levels before surgery are related to the pathological type. As already shown, serum CEA levels differed among

Table 3 Serum CEA level and EGFR mutation/ALK fusion

\begin{tabular}{|c|c|c|c|c|c|c|}
\hline CEA $(n g / m L)$ & $\mathbf{n}$ & $\begin{array}{l}\text { EGFR } \\
\text { mutation, n (\%) }\end{array}$ & $\begin{array}{l}\text { EGFR } 19 \text { mutation } \\
(n=\mid 35), n(\%)\end{array}$ & $\begin{array}{l}\text { EGFR 2I L858R } \\
\text { mutation ( } n=\mid 53), n \text { (\%) }\end{array}$ & $\begin{array}{l}\text { EGFR rare } \\
\text { mutation, } \mathrm{n}(\%)\end{array}$ & $\begin{array}{l}\text { ALK refusion } \\
(n=20), n(\%)\end{array}$ \\
\hline$<5$ & 310 & 221 (7I.3) & $100(32.3)$ & 105 (33.9) & $17(5.5)$ & I5 (4.8) \\
\hline$\geq 5$ & 132 & $88(66.7)$ & $36(27.3)$ & $48(36.4)$ & $4(3.0)$ & $5(3.8)$ \\
\hline $6-19$ & 97 & $62(63.9)$ & $23(23.7)$ & $35(36.1)$ & $4(4.1)$ & $3(3.1)$ \\
\hline$\geq 20$ & 35 & $26(74.3)$ & I $3(37.1)$ & $13(37.1)$ & 0 & $2(5.7)$ \\
\hline $21-49$ & 17 & 15 (88.2) & $9(52.9)$ & $6(35.3)$ & 0 & 0 \\
\hline$\geq 50$ & 18 & II (6I.I) & $4(22.22)$ & $7(38.9)$ & 0 & $2(1 \mathrm{I} .1)$ \\
\hline
\end{tabular}

Abbreviations: CEA, carcinoembryonic antigen; EGFR, epidermal growth factor receptor; ALK, anaplastic lymphoma kinase. 
Table 4 Clinicopathologic characteristics of lung cancer patients with CEA $>20 \mathrm{ng} / \mathrm{mL}$ and CEA $\leq 20 \mathrm{ng} / \mathrm{mL}$

\begin{tabular}{|c|c|c|c|c|c|}
\hline Variables & $n=442$ & $\begin{array}{l}\text { CEA }>20 \mathrm{ng} / \mathrm{mL} \\
(\mathrm{n}=35)\end{array}$ & $\begin{array}{l}\text { CEA } \leq 20 \mathrm{ng} / \mathrm{mL} \\
(\mathrm{n}=407)\end{array}$ & $P$-value & Chi-square \\
\hline Sex & & & & 0.861 & 0.042 \\
\hline Male & 184 & 14 & 170 & & \\
\hline Female & 258 & 21 & 237 & & \\
\hline Age (years) & & & & 0.702 & 0.283 \\
\hline$<65$ & 308 & 23 & 285 & & \\
\hline$\geq 65$ & 134 & 12 & 122 & & \\
\hline Smoking status & & & & 0.510 & 0.736 \\
\hline No smoking & 311 & 23 & 288 & & \\
\hline Light smoking $(\leq 20)$ & 42 & 3 & 39 & & \\
\hline Moderate smoking (2I-39) & 35 & 2 & 33 & & \\
\hline Heavy smoking $(\geq 40)$ & 54 & 7 & 47 & & \\
\hline $\mathrm{T}$ & & & & 0.001 & 16.007 \\
\hline Tla & 119 & 2 & 117 & & \\
\hline TIb & 70 & 2 & 68 & & \\
\hline T2a & 210 & 21 & 189 & & \\
\hline $\mathrm{T} 2 \mathrm{~b}$ & 21 & 5 & 16 & & \\
\hline T3 & 16 & 4 & 12 & & \\
\hline $\mathrm{T} 4$ & 5 & I & 4 & & \\
\hline$N$ & & & & 0.019 & 5.824 \\
\hline No & 310 & 12 & 298 & & \\
\hline $\mathrm{NI}$ & 41 & 7 & 34 & & \\
\hline N2 & 90 & 16 & 74 & & \\
\hline Stage & & & & 0.002 & $10.44 \mid$ \\
\hline IA & 150 & 2 & 148 & & \\
\hline IB & 140 & 5 & 135 & & \\
\hline IIA & 41 & 8 & 33 & & \\
\hline IIB & 15 & 2 & 13 & & \\
\hline IIIA & 96 & 18 & 78 & & \\
\hline Histologic subtype & & & & 0.114 & 2.971 \\
\hline Acinar & 233 & 24 & 209 & & \\
\hline Lepidic & 82 & 1 & 81 & & \\
\hline Papillary & 68 & 2 & 66 & & \\
\hline Micropapillary & 14 & 0 & 14 & & \\
\hline Solid & 43 & 8 & 35 & & \\
\hline Mucinous predominant & 2 & 0 & 2 & & \\
\hline EGFR mutation & 309 & 26 & 283 & 0.000 & |47.228 \\
\hline EGFR 19 mutation & 135 & 13 & 122 & 0.375 & 3.117 \\
\hline EGFR 21 mutation & 153 & 13 & 140 & & \\
\hline Rare mutation & 26 & 0 & 26 & & \\
\hline ALK fusion & 20 & 2 & 18 & 0.000 & $4|4.7| I$ \\
\hline
\end{tabular}

Abbreviations: CEA, carcinoembryonic antigen; EGFR, epidermal growth factor receptor; ALK, anaplastic lymphoma kinase; T, tumor; N, lymph node.

the histologic subtypes of lung adenocarcinoma. Specifically, CEA levels in patients with the solid subtype were higher than those of other histologic subtypes. These data indicated that the solid subtype (with higher CEA levels) might show poorer prognosis than the other histologic subtypes. The EGFR mutation status and CEA expression levels play important roles in the complex network of signal transduction pathways that regulate cell apoptosis. CEA is an adhesion protein whose expression can be activated and adjusted by EGFR signaling, which may be one of the reasons why CEA expression appears to be upregulated following EGFR mutation. ${ }^{18}$ A high prevalence of EGFR mutations was found in the current study population (69.9\%); previous studies reported that pure or mixed ground-glass opacity and the lepidic dominant histologic subtype could be good predictors of EGFR mutation in lung adenocarcinoma. ${ }^{19}$ In this study, we showed that EGFR mutations occurred more frequently in patients with IA, N0, and the lepidic subtype. This might be because lepidic dominant lung adenocarcinoma has low incidence of lymphatic vessel invasion. ${ }^{20}$

Serum CEA levels can clearly and consistently be considered to be normal or abnormal with a set cutoff value. 
Table 5 Multivariate analysis of relationship between CEA (cutoff $20 \mathrm{ng} / \mathrm{mL}$ ) and clinicopathologic characteristics in lung cancer patients

\begin{tabular}{|c|c|c|c|c|}
\hline \multirow[t]{2}{*}{ Variables } & \multirow[t]{2}{*}{$P$-value } & \multirow[t]{2}{*}{ Risk ratio } & \multicolumn{2}{|c|}{$\begin{array}{l}95 \% \mathrm{Cl} \text { for } \\
\text { risk ratio }\end{array}$} \\
\hline & & & Lower & Upper \\
\hline Sex & 0.400 & 1.675 & 0.504 & 5.569 \\
\hline Age & 0.245 & 1.632 & 0.715 & 3.724 \\
\hline Smoking status & 0.679 & 0.629 & 0.070 & 5.643 \\
\hline Stage & 0.304 & 1.953 & 0.545 & 6.998 \\
\hline $\mathrm{T}$ & 0.029 & 1.670 & 1.053 & 2.647 \\
\hline $\mathrm{N}$ & 0.591 & 1.375 & 0.431 & 4.386 \\
\hline Histologic subtype & 0.503 & 0.910 & 0.691 & 1.199 \\
\hline EGFR mutation & 0.033 & 5.559 & $\mathrm{I} .148$ & 26.924 \\
\hline ALK fusion & 0.323 & 2.389 & 0.424 & 13.448 \\
\hline
\end{tabular}

Abbreviations: CEA, carcinoembryonic antigen; $\mathrm{Cl}$, confidence interval; EGFR, epidermal growth factor receptor; ALK, anaplastic lymphoma kinase; T, tumor; $\mathrm{N}$, lymph node.

Several studies have revealed the prognostic value of preoperative serum CEA levels. Consistently, in this study, serum CEA expression levels were positively correlated with EGFR mutations; indeed, EGFR mutation occurrence rates increased with serum CEA levels, corroborating findings by Cai. ${ }^{21}$ Hence, the EGFR mutation profile can be preliminarily forecasted using preoperative CEA levels. Serum CEA $>20 \mathrm{ng} / \mathrm{mL}$ predicted an elevation of EGFR mutation rate; the reason might be that activation of molecules downstream of EGFR mutant promotes anti-apoptosis, while CEA expression is enhanced by EGFR.

It was reported that ALK defines specific molecular subsets of lung adenocarcinomas with distinct clinical features. In the present study, high preoperative serum CEA levels (CEA > $20 \mathrm{ng} / \mathrm{mL}$ ) were independently associated with ALK fusion protein expression; however, the sample size was relatively small, and large sample trials are required for confirmation.

Furthermore, clinicopathologic characteristics between the CEA $>20 \mathrm{ng} / \mathrm{mL}$ and CEA $\leq 20 \mathrm{ng} / \mathrm{mL}$ groups were analyzed; interestingly, EGFR mutation and T stage were independent risk factors for high CEA levels.

Tomita et $\mathrm{a}^{22}$ demonstrated that lower CEA levels result in higher 5-year disease-specific survival, whereas Maeda et $\mathrm{al}^{23}$ considered CEA level an important clinical predictor of tumor invasiveness and lymph node metastasis. In future studies, the association of CEA expression with the prognosis of patients with lung adenocarcinoma will be evaluated.

\section{Conclusion}

Preoperative serum CEA levels have certain value for predicting the histologic subtype, as well as EGFR mutation or
ALK fusion protein status, in lung adenocarcinoma patients. Moreover, histological subtypes could also predict EGFR mutations.

\section{Acknowledgment}

This work was supported by the 1022 Talent Training Program of Zhejiang Cancer Hospital.

\section{Disclosure}

The authors report no conflicts of interest in this work.

\section{References}

1. Rosell R, Moran T, Queralt C, et al; Spanish Lung Cancer Group. Screening for epidermal growth factor receptor mutations in lung cancer. N Engl J Med. 2009;361(10):958-967.

2. Wu YL, Zhong WZ, Li LY, et al. Epidermal growth factor receptor mutations and their correlation with gefitinib therapy in patients with non-small cell lung cancer: a meta-analysis based on updated individual patient data from six medical centers in mainland China. $J$ Thorac Oncol. 2007;2(5):430-439.

3. Lu HY, Su D, Pan XD, Jiang H, Ma SL. Mutation and expression of multiple treatment response-related genes in a population with locally advanced non-small cell lung cancer. Oncol Lett. 2012;3(2): 415-420.

4. Zhou C, Wu YL, Chen G, et al. Erlotinib versus chemotherapy as first-line treatment for patients with advanced EGFR mutationpositive non-small-cell lung cancer (OPTIMAL, CTONG-0802): a multicentre, open-label, randomised, phase 3 study. Lancet Oncol. 2011;12(8):735-742.

5. Fukuoka M, Wu YL, Thongprasert S, et al. Biomarker analyses and final overall survival results from a phase III, randomized, open-label, first-line study of gefitinib versus carboplatin/paclitaxel in clinically selected patients with advanced non-small-cell lung cancer in Asia (IPASS). J Clin Oncol. 2011;29(21):2866-2874.

6. Soda M, Choi YL, Enomoto M, et al. Identification of the transforming EML4-ALK fusion gene in non-small-cell lung cancer. Nature. 2007;448(7153):561-566

7. Paik JH, Choe G, Kim H, et al. Screening of anaplastic lymphoma kinase rearrangement by immunohistochemistry in non-small cell lung cancer: correlation with fluorescence in situ hybridization. $J$ Thorac Oncol. 2011;6(3):466-472.

8. Kwak EL, Bang YJ, Camidge DR, et al. Anaplastic lymphoma kinase inhibition in non-small-cell lung cancer. N Engl J Med. 2010; 363(18):1693-1703

9. Solomon BJ, Mok T, Kim DW, et al; PROFILE 1014 Investigators. First-line crizotinib versus chemotherapy in ALK-positive lung cancer. N Engl J Med. 2014;371(23):2167-2177.

10. Blackhall F, Kim DW, Besse B, et al. Patient-reported outcomes and quality of life in PROFILE 1007: a randomized trial of crizotinib compared with chemotherapy in previously treated patients with ALK-positive advanced non-small-cell lung cancer. $J$ Thorac Oncol. 2014;9(11):1625-1633.

11. Toyokawa G, Seto T, Takenoyama M, Ichinose Y. Insights into brain metastasis in patients with ALK+ lung cancer: is the brain truly a sanctuary? Cancer Metastasis Rev. 2015;34(4):797-805.

12. Solomon BJ, Cappuzzo F, Felip E, et al. Intracranial efficacy of crizotinib versus chemotherapy in patients with advanced ALK-positive non-small-cell lung cancer: results from PROFILE 1014. J Clin Oncol. 2016;34(24):2858-2865.

13. Wang CY, Huang MS, Huang MH, Lee HC, Hsu HS. Persistently high serum carcinoembryonic antigen levels after surgery indicate poor prognosis in patients with stage I non-small-cell lung cancer. $J$ Surg Res. 2010;163(2):e45-e50. 
14. Molina R, Filella X, Augé JM, et al. Tumor markers (CEA, CA 125, CYFRA 21-1, SCC and NSE) in patients with non-small cell lung cancer as an aid in histological diagnosis and prognosis. Comparison with the main clinical and pathological prognostic factors. Tumour Biol. 2003;24(4):209-218.

15. Cui S, Xiong L, Lou Y, et al. Factors that predict progression-free survival in Chinese lung adenocarcinoma patients treated with epidermal growth factor receptor tyrosine kinase inhibitors. $J$ Thorac Dis. 2016;8(1):68-78.

16. Zhao H, Fan Y, Ma S, et al; INFORM investigators. Final overall survival results from a phase III, randomized, placebo-controlled, parallel-group study of gefitinib versus placebo as maintenance therapy in patients with locally advanced or metastatic non-small-cell lung cancer (INFORM; C-TONG 0804). J Thorac Oncol. 2015;10(4): 655-664.

17. Zhou J, Yao H, Zhao J, et al. Cell block samples from malignant pleural effusion might be valid alternative samples for anaplastic lymphoma kinase detection in patients with advanced non-small-cell lung cancer. Histopathology. 2015;66(7):949-954.

18. Kobayashi M, Takeuchi T, Ohtsuki Y. Establishment of three novel human malignant pleural mesothelioma cell lines: morphological and cytogenetical studies and EGFR mutation status. Anticancer Res. 2008;28(1A):197-208.
19. Lee HJ, Kim YT, Kang CH, et al. Epidermal growth factor receptor mutation in lung adenocarcinomas: relationship with CT characteristics and histologic subtypes. Radiology. 2013;268(1):254-264.

20. Araki K, Kidokoro Y, Hosoya K, et al. Excellent prognosis of lepidicpredominant lung adenocarcinoma: low incidence of lymphatic vessel invasion as a key factor. Anticancer Res. 2014;34(6):3153-3156.

21. Cai Z. Relationship between serum carcinoembryonic antigen level and epidermal growth factor receptor mutations with the influence on the prognosis of non-small-cell lung cancer patients. Onco Targets Ther. 2016;9:3873-3878.

22. Tomita M, Ayabe T, Chosa E, Nose N, Nakamura K. Prognostic significance of a tumor marker index based on preoperative serum carcinoembryonic antigen and Krebs von den Lungen-6 levels in non-small cell lung cancer. Asian Pac J Cancer Prev. 2017;18(1):287-291.

23. Maeda R, Suda T, Hachimaru A, Tochii D, Tochii S, Takagi Y. Clinical significance of preoperative carcinoembryonic antigen level in patients with clinical stage IA non-small cell lung cancer. $J$ Thorac Dis. 2017;9(1):176-186.
OncoTargets and Therapy

\section{Publish your work in this journal}

OncoTargets and Therapy is an international, peer-reviewed, open access journal focusing on the pathological basis of all cancers, potential targets for therapy and treatment protocols employed to improve the management of cancer patients. The journal also focuses on the impact of management programs and new therapeutic agents and protocols on

\section{Dovepress}

patient perspectives such as quality of life, adherence and satisfaction. The manuscript management system is completely online and includes a very quick and fair peer-review system, which is all easy to use. Visit http://www.dovepress.com/testimonials.php to read real quotes from published authors. 